\title{
In vitro inhibition of $H$. pylori in a preferential manner using bioengineered $L$. lactis releasing guided Antimicrobial peptides
}

\author{
Ankan Choudhury ${ }^{1}$, Patrick Ortiz ${ }^{1}$, Christopher M. Kearney ${ }^{1}$ \\ ${ }^{1}$ Baylor University, Department of Biology, Waco, TX, USA \\ Correspondence: \\ Christopher M. Kearney \\ Chris_Kearney@baylor.edu
}

\section{Abstract}

Objectives: Targeted therapies seek to selectively eliminate a pathogen without disrupting the resident microbial community. This is even more important when a pathogen like $H$. pylori resides in stomach, a sensitive microbial ecosystem. Using a probiotic like Lactococcus lactis and bioengineering it to release a guided Antimicrobial Peptide (AMP) targeted towards the pathogen offers a pathway to specifically knock-out the deleterious species and not disturbing the stomach microbiome.

Results: Three AMPs, Alyteserin, CRAMP and Laterosporulin, were genetically fused to a guiding peptide MM1, which selectively binds to Vacuolating Toxin A (VacA) of H. pylori and cloned into an excretory vector pTKR inside L. lactis. When cultured together in vitro, the L. lactis bioengineered with guided AMPs selectively killed H. pylori when compared to E. coli or Lactobacillus plantarum, as determined by qPCR. Chemically synthesized Alyteserin and MM1Alyteserin showed similar preferential inhibition of $H$. pylori when compared against $E$. coli, with the MIC of MM1-Alyteserin becoming significantly higher for E. coli than Alytserin whereas no such effet was observed against $H$. pylori. 
Conclusions: Probiotics bioengineered to excrete guided AMPs can be a novel and useful approach for combating pathogens without endangering the natural microbial flora. Given the wealth of AMPs and guiding ligands, both natural and synthetic, this approach can be adapted to develop a diverse array of chimeric guided AMPs and can be cloned into probiotics to create a safe and effective alternative to conventional chemical antibiotics.

\section{Introduction}

Helicobacter pylori is the source of one of the most prevalent infections in the world, with over $50 \%$ prevalence in many countries but often over $90 \%$ in Africa and East Asia (Salih, 2009). Over $60 \%$ of cases of gastric cancer can be attributed to $H$. pylori infection (Correa and Piazuelo, 2011), making it one of the most widespread cancers caused by an infectious agent (Wroblewski et al., 2010). Multidrug resistant strains of $H$. pylori constitute an increasing portion of $H$. pylori infections, from $>10 \%$ in European countries to $>40 \%$ of infections in Peru (Boyanova et al., 2019). Newest treatment regimens for $H$. pylori infection include triple and quadruple antibiotic therapies to match the growing challenge of antibiotic resistance. Such therapeutic regimens

44 include combinations of amoxicillin, tetracycline, bismuth, metronidazole, clarithromycin, and more. In return, quadruple, quintuple, and sextuple antibiotic-resistant strains have been detected (Boyanova et al., 2019). This escalation of antibiotic resistance in H. pylori has heightened the need for new therapeutic strategies to combat infection. The multiple actions of these antibiotics such as rRNA inhibition, $\beta$-lactams, nucleic acid inhibitors also deleteriously effect off target

49 bacteria, and a growing list of antibiotics administered to curb a single infection increases the 
52 into intestinal inflammatory diseases like colitis (Strati et al., 2021), worsens neuro-immune

53 mechanisms and viscerosensory functionalities (Aguilera et al., 2015) and often makes way for

54 bloom of pathogens (Vangay et al., 2015) creating other possibly more serious infectious diseases.

55 This presents a dilemma, as stronger small molecule antibiotics are required to kill bacteria with ever-evolving antibiotic resistance mechanisms, but stronger antibiotics kill a wider variety of commensal bacteria (Becattini et al., 2016; Langdon et al., 2016; Zarrinpar et al., 2018).

To meet the challenges associated with this infection, one strategy proposed has been the use of AMPs. AMP refers to a broad group of short, usually cationic peptides with bactericidal or bacteriostatic properties (Lei et al., 2019). Because many of them exhibit a broad mechanism of action that forms pores in bacterial membranes, it has been suggested that it may be more difficult for bacteria to evolve resistance mechanisms to these peptides than traditional antibiotic drugs, though resistance can still occur (Assoni et al., 2020; Di et al., 2020; El Shazely et al., 2020). While

64 the broad category of AMP comprises many diverse peptides that exhibit some antimicrobial activity, several specific types of AMP have been demonstrated to effectively kill $H$. pylori. 66 Cathelicidins such as LL-37 and its murine homolog Cathelin-related Antimicrobial Peptide 67 (CRAMP) have been demonstrated to effectively kill Helicobacter pylori in both in vitro and in vivo experiments (Hase et al., 2003; Zhang et al., 2016, 2013). Bacteriocins are small, stable AMPs released by other bacteria, that have broad bactericidal ability against a variety of gram-positive and gram-negative bacteria including H. pylori (Neshani et al., 2019). Among them, Type IId

71 bacteriocins including Laterosporulin has been well documented for their bactericidal activity with

72 well-established mechanisms (Baindara et al., 2016; Singh et al., 2015). As more novel AMPs 73 are discovered, a catalog of AMPs with activity against $H$. pylori has grown, showing promise as 74 potential therapeutics. 
While many of these AMPs have demonstrated effective antibacterial activity towards $H$.

pylori, they also kill many other bacterial taxa. The double-edged sword of antibacterial therapies is that they have the unintended consequence of killing commensal microbiota. To deal with the

78 problem of off target killing there have been several proposed solutions. Some AMPs naturally have increased activity towards specific bacterial taxa, and if utilized properly might avoid causing dysbiosis of microbiota in certain settings. Another option has been to modify AMPs, making chimeric peptides that use a short glycine linker and a guide peptide to "target" a specific taxon. Such guided antimicrobial peptides (gAMPs) have been shown to be effective in several settings against a variety of bacteria (Choudhury et al., 2020; Eckert et al., 2012, 2006; Kim et al., 2020).

In some cases, such constructs can be made to increase the toxicity of a relatively weak AMP towards a targeted bacterium (Eckert et al., 2006), whereas in others it has been demonstrated to decrease toxicity of a potent AMP towards off-target bacteria (Choudhury et al., 2020). Furthermore, while studies have shown the bactericidal effects of such gAMPs in an in-vivo setting, the selectivity of these constructs has not been demonstrated in-vivo to ascertain if the microbiota are relatively undisturbed; nor has a gAMP been utilized against $H$. pylori. One of the reasons for this is that delivery of engineered peptides may be difficult. Intraperitoneal injections of purified peptide have been used for gut infections, but infections of the stomach require a

92 delivery mechanism that will stand up to low $\mathrm{pH}$ conditions, peptidases, and provide delivery at the site of the infection. Antimicrobial peptides, being proteinaceous, are at a greater risk of enzymatic degradation through oral routes (Moncla et al., 2011; Svenson et al., 2008) and the high gastric acidity and peptidolytic enzymes cause breakdown of proteins and peptides when ingested orally. To avoid this gastric degradation, drugs are often delivered through systemic injection. For

97 peptides, this is problematic as the size and high molecular weight of proteinaceous drug make it 
an easier target for opsonization and neutralization by the blood complement system (Vaucher et al., 2011). Thus, for having the desired therapeutic effect the peptidic drug will have to survive the degradation in gut and reach the site of action. Encasing the antimicrobial peptide is in a delivery system that masks it to survive the journey in the oral delivery and release it once the site is reached would be of great help and would help in microbial infections along the gut for which oral delivery of drugs is necessary.

Employing food grade bacterial systems like the lactic acid bacteria can solve the problem of the peptide's survival through degradative environments such as the gastrointestinal tract (Steidler et al., 2003). These bacteria are adapted to survive, propagate and produce and secrete their indigenous proteins in low $\mathrm{pH}$ conditions of the stomach. Encoding the chimeric antimicrobial peptide into a secretion vector inside such lactic acid bacteria will ensure that the protein will survive the journey into the gastrointestinal tract and be released from the cell into the site of infection (Jeong et al., 2006; Li et al., 2011). The cells will act as a sustained release platform as the expression of the protein will happen over a time. The cells will also replicate and maintain a colony of drug-releasing bacteria for an extended period (Drouault et al., 1999), unlike conventional drug delivery system. This reduces the number of dosages required to maintain the effective drug level for treatment of the infection. The vector can also be modified to contain an inducible promoter that is pH dependent (de Vos, 1999; Madsen et al., 1999), like the heat shock and nitrogen dependent constitutive promoters. A promoter that is induced by low acidic $\mathrm{pH}$, like P1, P2 and P170 (de Vos, 1999; Madsen et al., 2005, 1999), will enable the lactic acid bacteria to express and secrete the encoded peptide only when it is exposed to such conditions at the target location in the gastric system. Thus, a lactic acid bacterium containing a secretion vector with a $\mathrm{pH}$ inducible promoter driving AMP expression constitutes an excellent sustained release drug 
121 delivery system that will protect the peptidic drug from the enzymatic degradation in the

122 gastrointestinal tract and deliver it to the proper target site. Lactic acid bacteria in the genera

123 Lactobacillus and Lactococcus have been a part of the human diet for millennia. There have been

124 numerous strains of lactic acid bacteria that are considered safe to consume and graded by the FDA

125 as such (Nutrition, 2020) Since early 2000s, Lactococcus lactis has proven to be an excellent

126 method for delivering engineered peptides in-situ from what has since burgeoned a variety of

127 engineered probiotic bacteria. These engineered probiotics have been used to deliver signaling

128 peptides, dyes, interleukins, and even unmodified AMPs (Foligne et al., 2007; Steidler et al., 2003,

129 1998). Lactococcus lactis also holds the distinction of being the first genetically engineered

organism to be used for a therapeutic application in humans (Braat et al., 2006).

In this paper, we will demonstrate the efficacy of L. lactis bioengineered to secrete AMPs

and gAMPs to inhibit $H$. pylori when co-cultured in vitro. We selected a suitable vector for such

purpose and then cloned it with 3 AMPs of our choice and their corresponding gAMPs. The

gAMPs were created by fusing a guiding peptide to the $\mathrm{N}$ - terminus of the corresponding AMP.

135 The principle behind our gAMPS was to find a unique and attractive target protein on the surface

137 pylori is a major cause for its pathogenicity and can either be released into extracellular space

138 (Cover and Blaser, 1992; Foegeding et al., 2016; Snider et al., 2016) or a significant portion of it

139 is left in the bacterial cell surface (Foegeding et al., 2016; McClain and Cover, 2006; Telford et

141 (Ilver et al., 2004; Keenan et al., 2000; McClain and Cover, 2006). VacA toxin (comprised of the

142 p33 and p55 subunits) binds to host cells and is internalized, causing severe "vacuolation" 
144 and early lysosomes (Foegeding et al., 2016; Palframan et al., 2012). The development of "vacuoles" has been attributed to the formation of VacA anion-selective channels in membranes. Apart from its vacuolating effects, it has recently become clear that VacA also directly affects mitochondrial function (Foo et al., 2010). The VacA toxin binds to stomach lining cells by associating with the lipid rafts on the cell membrane which causes it to be internalized by the cell and promote vacuole formation (Fiocca et al., 1999). Once internalized, the p34 subunit of VacA toxin also forms an anionic pore into the mitochondrial membrane and interfere with its function (Domańska et al., 2010). The vacA toxin has been studied for being a major virulence factor and hence its structures and associations are also explored. One such protein whose association with the VacA toxin was explored was Multimerin-1(Satoh et al., 2013). Multimerin-1 is a protein expressed on the surface of human platelets and is bound by the VacA toxin when it induces platelet CD62P expression76. It was shown that VacA would bind with a specified region of multimerin-1 from AA 321-340 stronger than any other region, making it the purported region for attachment with the platelets (Satoh et al., 2013). We used this peptide sequence, fused to the AMP, as a targeting domain against $H$. pylori. Expression will be driven by the low $\mathrm{pH}$ induced secretion vector in L. lactis. This will yield a live vector delivery system for AMP targeted towards only H. pylori and sparing other bacteria. al., 2004, 1998; van Asseldonk et al., 1990; Waterfield et al., 1995). pT1NX contains a native $L$. lactis promoter called P1 (Madsen et al., 2005) which is induced by the low $\mathrm{pH}$ conditions like in the stomach. P1 is also induced by thermal stress and have been seen to increase expression of 165 proteins 500 -fold when growth conditions are changed from $24^{\circ} \mathrm{C}$ to around $40^{\circ} \mathrm{C}$, which is closer 
167

168

169

170

171

172

173

174

175

176

177

178

179

180

181

182

usp45 (van Asseldonk et al., 1990) that secretes any expressed protein placed downstream of it in the ORF. Thus, placing the AMP or the gAMP placed downstream in the ORF of the vector will ensure that the usp45 signal peptide will secrete it outside the L. lactis cell surface and this expression and subsequent secretion will be governed by the P1 promoter which will trigger expression only in low $\mathrm{pH}$ conditions. The pT1NX vector was further modified by adding a Kanamycin Resistant domain to make it a dual bacteria vector and making it possible to be cloned into E. coli along with L. lactis.

\section{Methods and Materials}

\section{Cloning Antimicrobial peptides(AMPs) and guided Antimicrobial peptides (gAMPs) in L. lactis}

The ORFs of the AMPs (Table 3.1), codon-optimized for Lactococcus lactis were cloned into the modified pT1NX plasmid (pT1NX-Kanamycin resistant/pTKR, Figure 3.1) in between the restriction enzyme sites BamHI and SpeI by replacing the spaX protein of the original plasmid.

The P1 promoter upstream of the BamHI cut-site controls the downstream expression as a constitutive promoter which is upregulated by low $\mathrm{pH}$. The usp45 gene immediately upstream of BamHI site is an endogenous signal peptide of Lactococcus species that transports the attached protein to extracellular location.

After ligation of the AMP/gAMP into pTKR vector, it was transformed into E. coli (10 NEB) and plated onto Kanamycin selective plate. The pT1NX plasmid (LMBP 3498) has erythromycin resistance but pTKR is a dual vector with kanamyicin resistance for cloning into electrocompetent E. coli (10ß, NEB) for plasmid propagation. Extracted plasmid from the E. coli was then electroporated into electrocompetent L. lactis MG1363 (LMBP 3019) and plated on erythromycin selective GM17 plate $\left(30^{\circ} \mathrm{C}\right.$, microaerobic, overnight). After screening for the 
presence of the AMP/gAMP ORFs with PCR, selected colonies are propagated in liquid cultures of M17 broth with Glucose $(0.5 \% \mathrm{w} / \mathrm{v})$ in the presence of erythromycin $(5 \mu \mathrm{g} / \mathrm{ml})$.

\begin{tabular}{|c|l|}
\hline AMP/gAMP & \multicolumn{1}{c|}{ Peptide Sequence } \\
\hline Laterosporulin & $\begin{array}{l}\text { ACQCPDAISGWTHTDYQCHGLENKMYRHVYAICMNGTQV } \\
\text { YCRTEWGSSC }\end{array}$ \\
\hline $\begin{array}{c}\text { Multimerin1(MM1)- } \\
\text { Laterosporulin }\end{array}$ & $\begin{array}{l}\text { MQKMTDQVNYQAMKLTLLQKSGGGSACQCPDAISGWTH } \\
\text { TDYQHGLENKMYRHVYAICMNGTQVYCRTEWGSSC }\end{array}$ \\
\hline Alyteserin & GLKDIFKAGLGSLVKGIAAHVAN \\
\hline MM1-Alyteserin & $\begin{array}{l}\text { MQKMTDQVNYQAMKLTLLQKSGGGSGLKDIFKAGLGSLV } \\
\text { KGIAAHVAN }\end{array}$ \\
\hline CRAMP & ISRLAGLLRKGGEKIGEKLKKIGQKIKNFFQKLVPQPE \\
\hline MM1-CRAMP & $\begin{array}{l}\text { MQKMTDQVNYQAMKLTLLQKSGGGSISRLAGLLRKGGEK } \\
\text { IGEKLKKIGQKIKNFFQKLVPQPE }\end{array}$ \\
\hline \multicolumn{2}{|c|}{ Blue = Multimerin1, Red = linker } \\
\hline
\end{tabular}

TABLE 1. The peptide sequences of 3 AMPs and their corresponding gAMPs with Multimerin1 fragment fused to the $\mathrm{N}$-terminus separated by a linker 


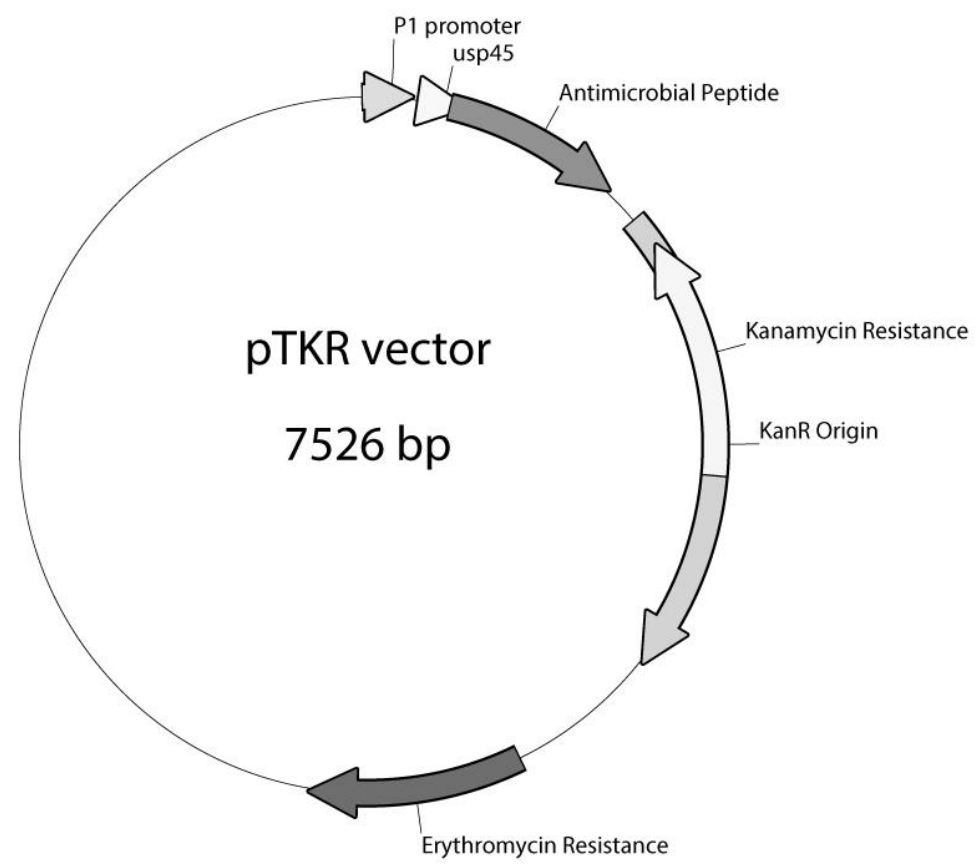

(A)

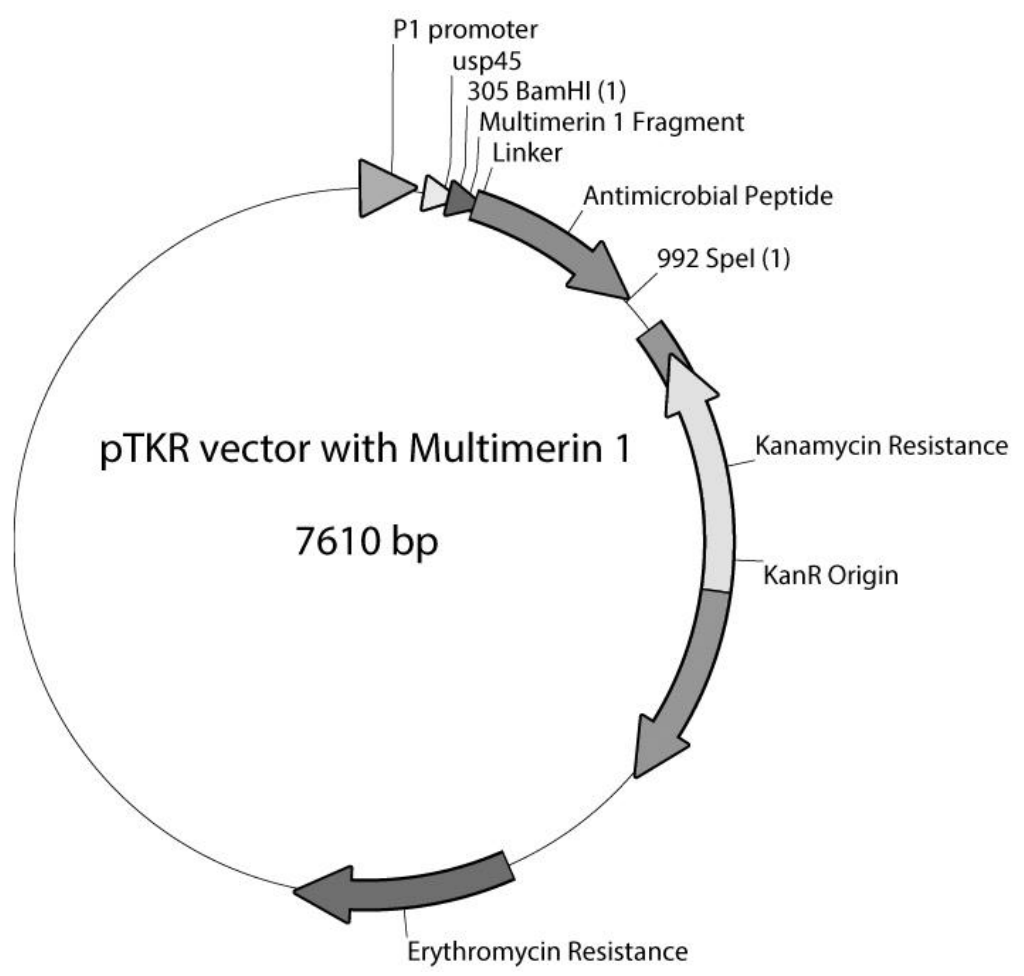

(B)

FIGURE 1. pTKR (pT1NX with kanamycin resistance gene) vector with the AMP sequence (A) and the MM1AMP/gAMP sequence (B) in between the BamHI and SpeI cutsites downstream of P1 promoter and usp45 sequence. 
In vitro assay: Co-culture assays with cloned L. lactis and $H$. pylori SS1

Desired variant of L. lactis cloned with AMP/tAMP were propagated from glycerol stocks and grown in GM17 broth overnight with erythromycin $(5 \mu \mathrm{g} / \mathrm{ml})$ with no shaking. H. pylori SS1 stocks were first propagated on Blood-Tryptic Soy agar (TSA) overnight with microaerobic condition and $>5 \% \mathrm{CO}_{2}$ environment. Then colonies from the plate were transferred to a TS broth with 5\% Newborn Calf serum (NCS) and grown overnight under microaerobic condition and $>5 \%$ $\mathrm{CO}_{2}$ environment. The $L$. lactis cultures were serially diluted in a 96 well culture plate with TS broth to make up a volume of $100 \mu \mathrm{L}$. To each well, $10 \mu \mathrm{L}$ of the overnight $H$. pylori culture were added and each well volume was brought up to $200 \mu \mathrm{L}$ with more TS broth. The plate is left to grow overnight in a microaerobic environment with $>5 \% \mathrm{CO}_{2}$. After $24 \mathrm{hrs}$, the each well content from the culture plate is transferred on a 96 well PCR plate. That PCR plate was sealed and heated for $15 \mathrm{~min}$ at $100^{\circ} \mathrm{C}$ and chilled at $4^{\circ} \mathrm{C}$ for $5 \mathrm{~min}$. Then the plate was centrifuged at $2000 \mathrm{~g}$ for 2 min and the supernatant was used as the template for qPCR. The qPCR was done using primers for VacA gene to quantify $H$. pylori (forward: 5'-ATGGAAATACAACAAACACAC-3', reverse: 5'-CTGCTTGAATGCGCCAAAC-3') and primers for acma gene for quantifying L. lactis (forward: 5' GGAGCTCGTGAAAGCTGACT 3', reverse: 5' GCCGGAACATTGACAACCAC 3'). Standard curves for $H$. pylori and L. lactis were constructed by determining $\mathrm{C}_{\mathrm{T}}$ values for different dilutions of the overnight cultures of the respective bacteria $(1 / 10,1 / 100,1 / 1000$, 1/10000) in the qPCR plates, the CFUs for the dilutions were determined by plating on their respective agar plates. Same procedure was followed by co-culturing Lactobacillus plantarum and E. coli with serially diluted cultures of $L$. lactis for $24 \mathrm{hrs}$ and their amount was determined by qPCR using primers for species specific genes for either bacteria. The amount of L. lactis added to the co-cultures of all the three assays ranged from around 4000 to $512000 \mathrm{CFU} / \mathrm{ul}$. 

respective microaerobic and aerobic conditions.

\section{Results}

247 pylori when plated. The gAMP containing L. lactis had similar bactericidal effect on $H$. pylori as 
250

251

252

253

254

255

concentration of $64,000 \mathrm{CFU} / \mathrm{ul}$ of L. lactis, reduced the H. pylori load to $1 / 30^{\text {th }}$ of the H. pylori load when co-cultured with $L$. lactis with empty vector at similar concentration on average, with MM1-Alyteserin-L. lactis reducing it to $1 / 1000^{\text {th }}$. The average reduction of $H$. pylori by the AMP$L$. lactis was only $1 / 6^{\text {th }}$ of that with the $L$. lactis containing empty vector, with Laterosporulin- $L$. lactis performing the best at $1 / 60^{\text {th }}$ reduction at $64,000 \mathrm{CFU} / \mathrm{ul}$. The reduction of $H$. pylori load increased with the concentration of $L$. lactis for both AMP and gAMP containing L. lactis.

Growth of $H$. pylori after $24 \mathrm{~h}$ co-culturing with L. lactis

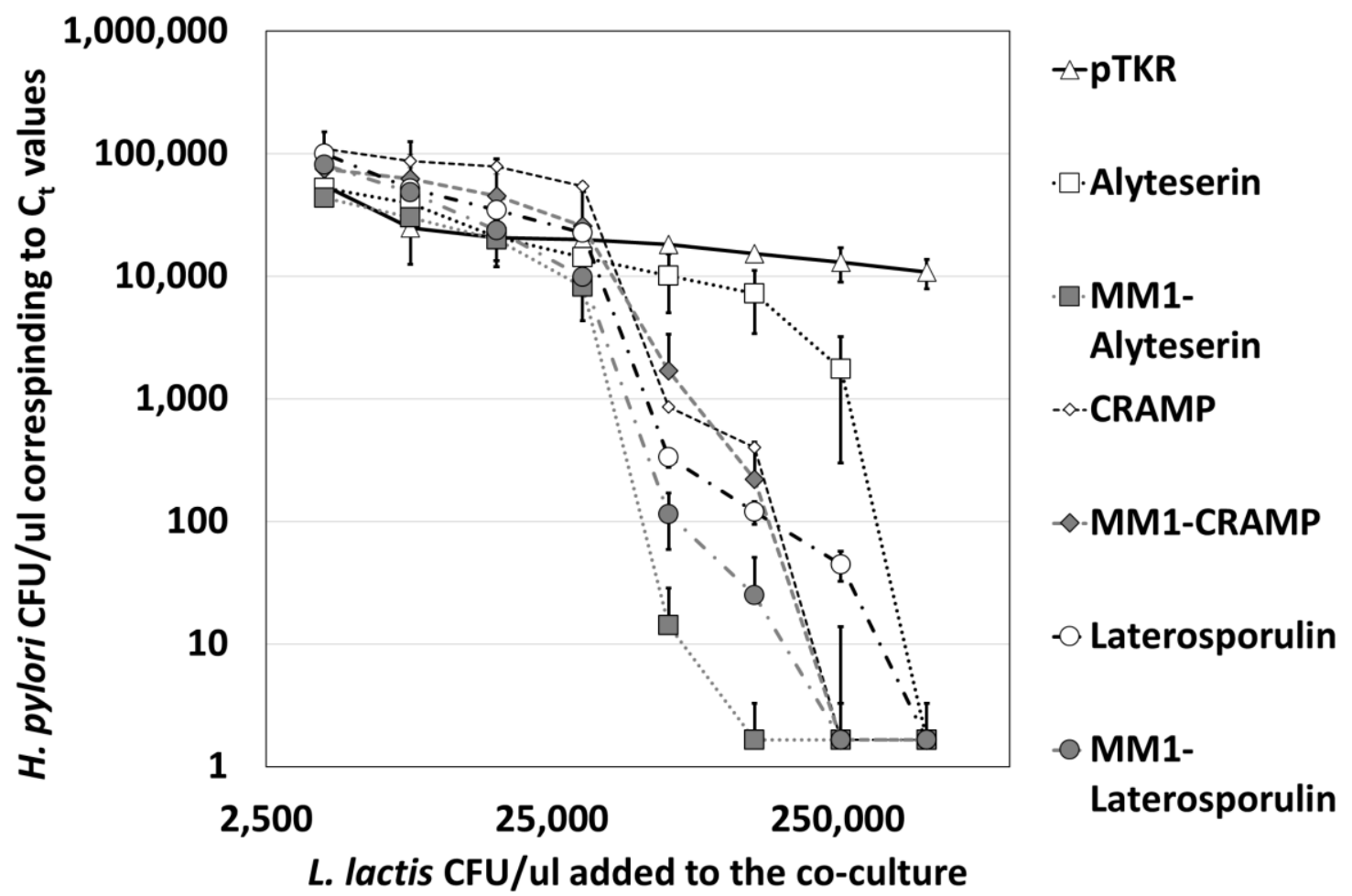

FIGURE 2. The CFU/ $\mu$ l of $H$. pylori grown in the co-culture after $24 \mathrm{hrs}$ of incubation, estimated from the corresponding $\mathrm{C}_{\mathrm{t}}$ values determined by $\mathrm{qPCR}$, plotted against the $\mathrm{CFU} / \mu \mathrm{l}$ of $L$. lactis added to the co-culture

But when co-cultured with L. plantarum (Figure 3) and E. coli (Figure 4), the gAMP-L. lactis had significantly less bactericidal action on either bacterium compared to their corresponding AMP- $L$. lactis. The difference in reduction of both E. coli and L. plantarum was evident even at the lowest 
concentration of $L$. lactis given (4000 CFU/ $\mu 1)$. The bacterial load of E. coli and L. plantarum for the gAMP-L. lactis by $3.4 \mathrm{x}$ and $1.8 \mathrm{x}$ times higher on average respectively than the bacterial load when cultured with AMP-L. lactis at even $4000 \mathrm{CFU} / \mu \mathrm{l}$, and the difference tapered with the increase in load of $L$. lactis upto $512000 \mathrm{CFU} / \mu 1$. Hence, we can see that the $L$. lactis releasing gAMPs had significantly lesser killing potential for non- $H$. pylori bacteria than the L. lactis releasing corresponding AMPs, and this difference is only erased with exponentially higher doses of L. lactis. But inversely, gAMP releasing L. lactis killed H. pylori at almost similar rate with the AMP-L. lactis with MM1-Alyteserin performing the best among all the 6 AMP and gAMP tested.

\section{Growth of Lactobacillus sp. after $24 \mathrm{~h}$ co-culturing with L. lactis}

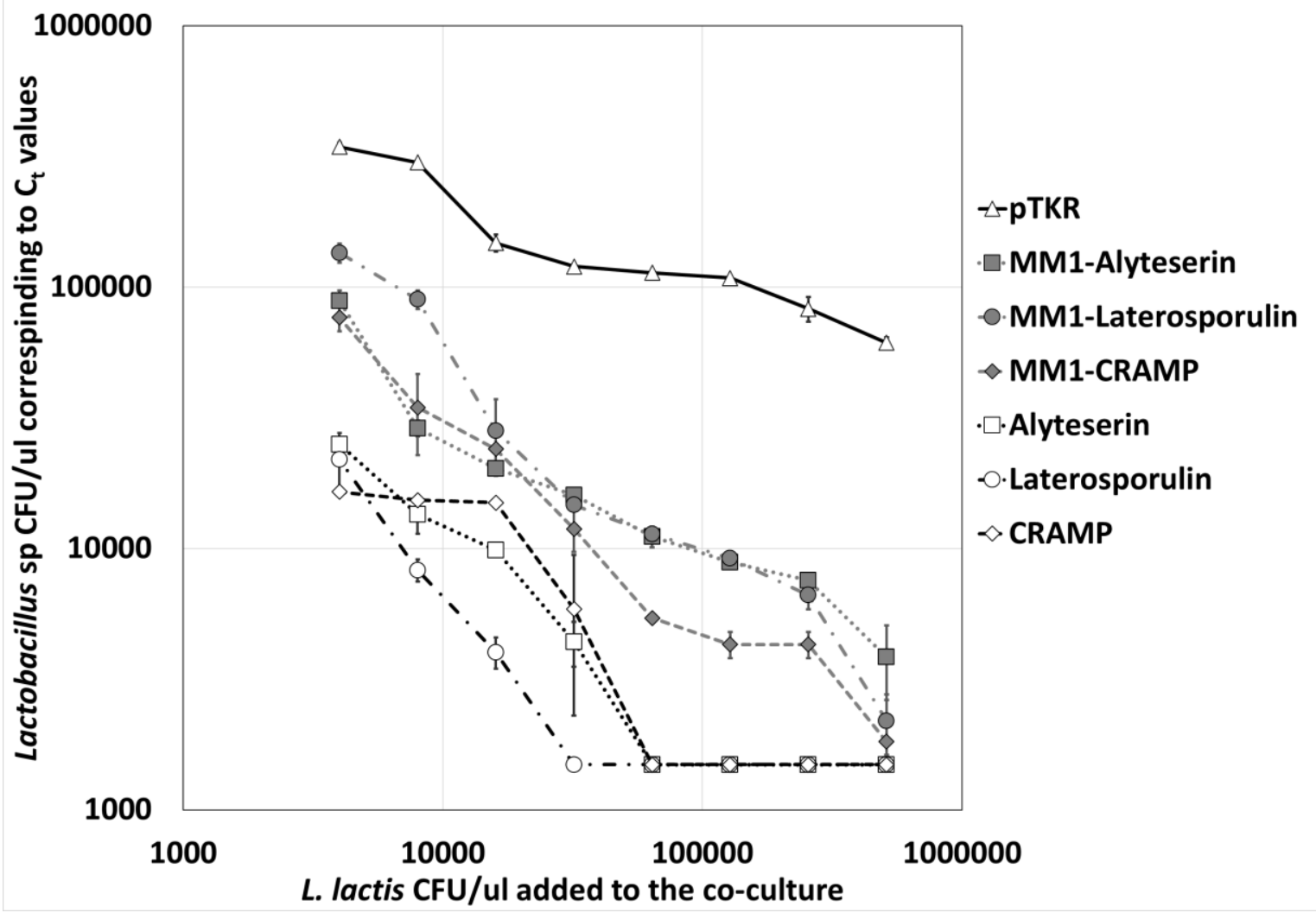




\section{Growth of $E$. coli after $24 \mathrm{~h}$ co-culturing with L. lactis}

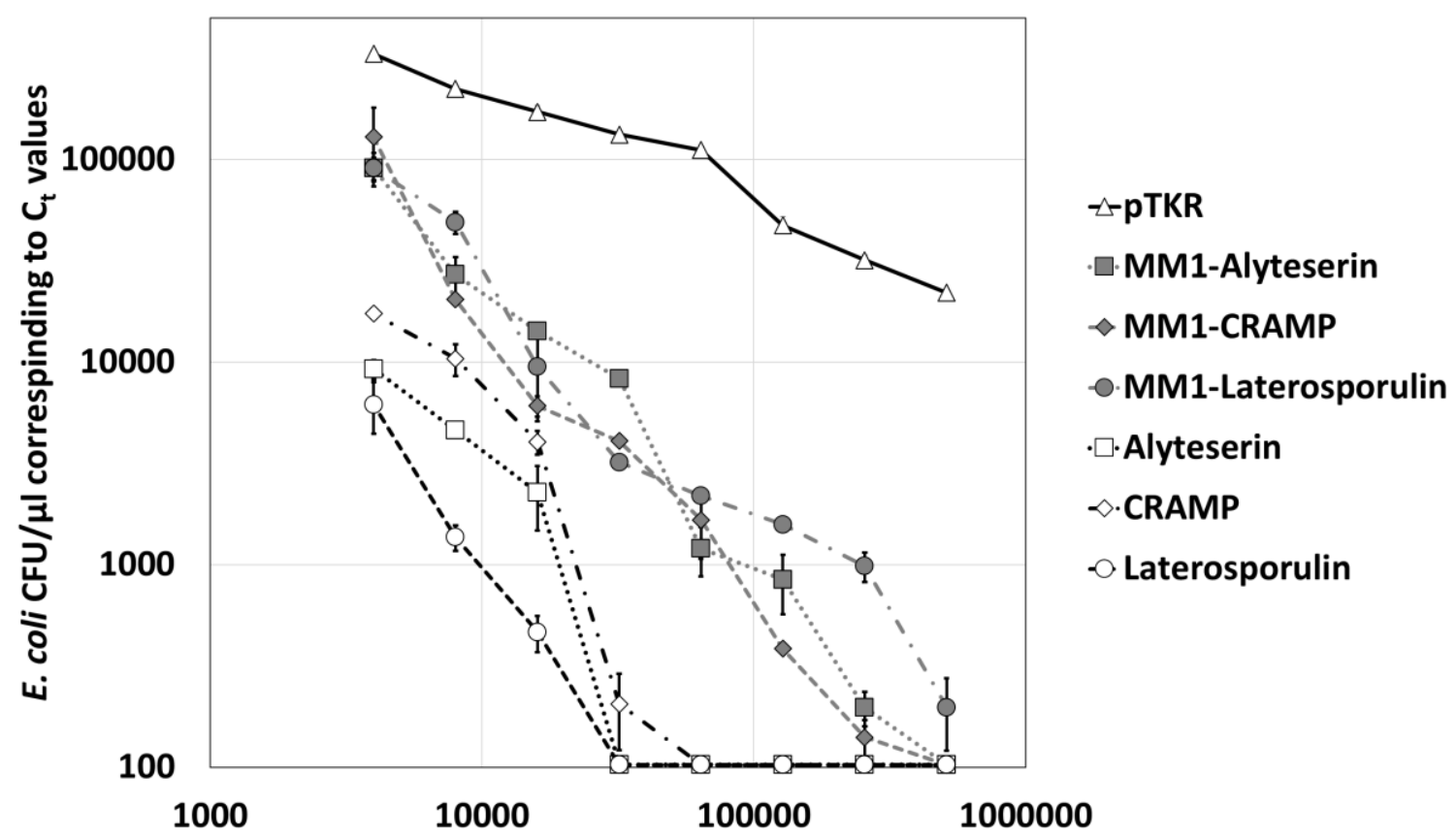

L. lactis $\mathrm{CFU} / \mu$ ladded to the co-culture

FIGURE 4. The CFU/ul of E. coli found in the co-culture after $24 \mathrm{hrs}$ of incubation, estimated from the corresponding $\mathrm{C}_{\mathrm{t}}$ values determined by qPCR, plotted against the CFU/ul of $L$. lactis added to the co-culture

Chemically synthesized gAMP showed preferential bactericidal activity towards $H$. pylori over E. coli

Bacterial inhibition assay with the chemically synthesized peptide demonstrated that Alyteserin when conjugated with the MM1 fragment domain had preferential inhibitory action against $H$. pylori over the non-target bacteria $E$. coli. The MIC recorded against $H$. pylori and $E$. coli for both Alyteserin and MM1-Alyteserin is shown in Table 2 and the mean values are shown graphically in Figure 5. The MIC against H. pylori for Alyteserin and MM1-Alyteserin were not significantly different even though MM1-Alyteserin had a lower MIC but the MIC against $E$. coli the MIC for MM1-ALytserin was significantly higher $(\mathrm{p}<0.01)$ than that of Alyteserin, thus showing that MM1-Alyteserin shows significantly lower bactericidal activity towards the nontarget $E$. coli compared to H. pylori. This echoes the results seen when the L. lactis cloned with 
AMPs and gAMPs were co-cultured with $H$. pylori and the non-target bacteria $E$. coli and $L$. plantarum.

\begin{tabular}{|c|c|c|c|c|}
\hline Bacteria & MIC $(\mu \mathrm{M})$ & Alyteserin & MM1-Alyteserin & P-value \\
\hline \multirow{2}{*}{ H. pylori } & Mean & 83.8 & 61.2 & 0.1475 \\
& SE & 5.429 & 10.842 & \\
\hline \multirow{2}{*}{ E. coli } & Mean & 25.2 & 160.8 & 0.0004 \\
& SE & 1.906 & 11.80 & \\
\cline { 2 - 5 } & & & & \\
\hline
\end{tabular}

290
TABLE 2. Minimum Inhibitory Concentration (MIC) exhibited by chemically synthesized Alyteserin and MM1Alyteserin against $H$. pylori and E. coli.

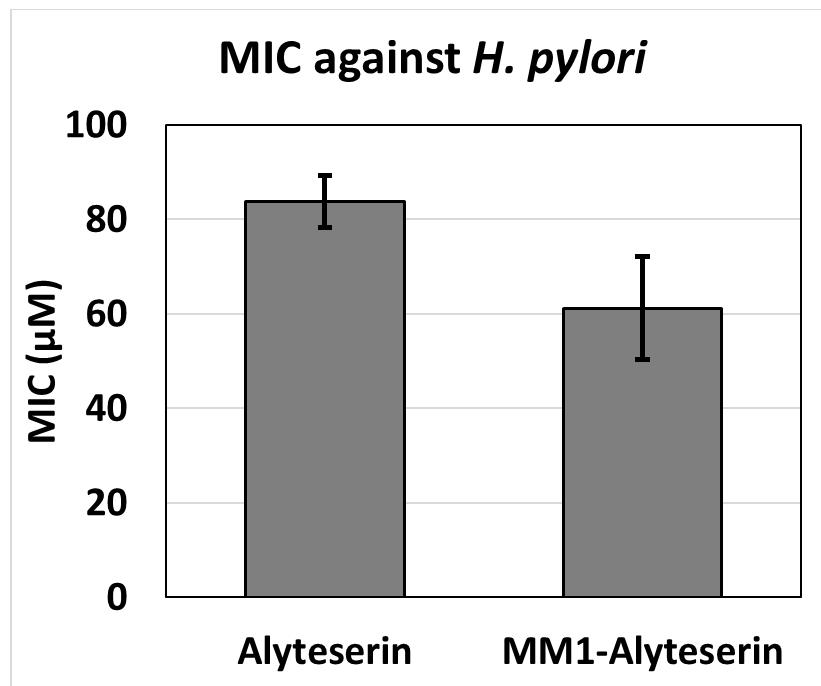

(A)

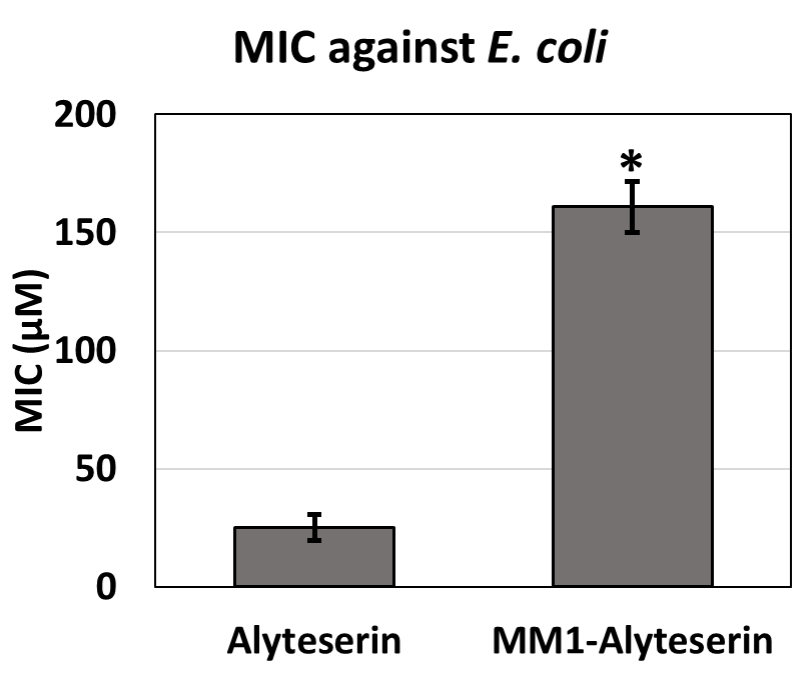

(B)

FIGURE 5. MIC values ( $\mu \mathrm{M})$ of Alyteserin and MM1-Alyteserin against H.pylori (A) and E. coli (B) 


\section{Discussion}

Both the in vitro assays using L. lactis cloned with AMP/gAMP and using chemically synthesized Alyteserin/MM1- Alyteserin demonstrated effective inhibtion of H. pylori. Co-culture assays showed that the L. lactis cloned with gAMPs that the Multimerin-1 fragment attached to it had similar efficacy against $H$. pylori to that of the L. lactis cloned with their AMP counterparts, with MM1-Alyteserin being the only gAMP that had significantly better microbicidal effect than its AMP counterpart. The measure of microbicidal effect was done by the estimating the CFU/ $\mu 1$ of $H$. pylori in the co-culture after overnight incubation with a particular concentration of bioengineered L. lactis, the lesser $H$. pyloti load the better microbicidal action exhibited. So, we can assume that attachment of MM1 fragment did not necessarily turn the AMP a more potential killer of the target bacteria, H. pylori. But when looking at the effect on the other two nonHelicobacter species; E. coli and L. plantarum, we see that the gAMPs with MM1 fragment had a significant drop in their microbicidal effect as a higher CFU/ul of gAMP-L. lactis were required to get a similar drop in non-target bacterial load exhibited by a lower CFU/ml dose of AMP- $L$. lactis. Hence, similar concentration of gAMP-L. lactis that caused a significant reduction in $H$. pylori $\mathrm{CFU} / \mu \mathrm{l}$ did not have the same effect on either $E$. coli or $L$. plantarum unlike the AMP-L. lactis which had similar microbicidal effect on all three bacteria. This shows that the gAMPs released by the L. lactis did not kill the non-target bacteria as it would $H$. pylori, proving that it has achieved an extent of specificity towards $H$. pylori. The fragment of MM1 that we used was found to have the highest dissociation coefficient $\left(K_{D}\right)$ with the vacA toxin on the surface of the H. pylori and may facilitate the attachment of the AMP to the bacteria. This enhanced attachment may not enhance the toxic effect that much as the amount of gAMP molecules approaching the bacterial cell membrane is not significantly different than the AMP molecules and attachment of 
gAMP molecules to the membrane above the saturation concentration does not necessarily make it more toxic. But the MM1 fragment may be an impairment to the attachment of the gAMP molecules to the non-target bacterial cell membrane and hence deceasing attachment which translates to decreased toxicity. This effect has also been seen in previous literature where targeting moieties did not necessarily enhance the toxic activity but rather decreased action against the other non-target bacteria. This ensures that the gAMPs have a certain specificity towards the bacteria they are designed to kill and sparing other non-target species which may be beneficial to the host microbiome.

When using a chemically synthesized version of the peptide Alyteserin and MM1-Alyteserin too reflected the preferential microbicidal tendency when their MICs were determined against $H$. pylori and E coli. Alyteserin is a class of AMPs among which Alyteserin-1 types show specific activity against Gram negative bacteria (Conlon et al., 2009). We used a specific sequence of an Alyteserin 1 peptide that has been used against Gram negative bacteria like E. coli (Conlon et al., 2009), Salmonella sp. (Volzing et al., 2013), Acinetobacter sp. (Conlon et al., 2010). The assay showed it to have similar MIC against $E$. coli as reported previously ( 25 $\mu \mathrm{M})$ but that MIC was increased significantly when using MM1-Alyteserin whereas there was no significant changes between the MICs of either Alyteserin and MM1 Alyteserin against H. pylori, albeit the MM1 Alyteserin having a lower MIC against $H$. pylori though it was not significant. This again proves the validity of our argument for using MM1 as a targeting domain and corroborates the data we got with co-culture assay using cloned L. lactis to inhibit $H$. pylori instead of synthesized peptides as the peptides have a danger of getting degraded when administered orally. And since both the naked peptide and the cloned L lactis showed efficacy in killing $H$. pylori we can use the latter as 
bioRxiv preprint doi: https://doi.org/10.1101/2021.06.11.448109; this version posted June 11, 2021. The copyright holder for this preprint (which was not certified by peer review) is the author/funder, who has granted bioRxiv a license to display the preprint in perpetuity. It is made available under aCC-BY-NC-ND 4.0 International license.

347 a model of therapeutic against the pathogen instead of the former and making it a more suited candidate for oral administration. 


\section{References}

A, V.R., C, V.G.C., Ap, C., V, S., J, F., A, B., 2011. Evaluation of the immunogenicity and in vivo toxicity of the antimicrobial peptide P34. Int J Pharm 421, 94-98. https://doi.org/10.1016/j.ijpharm.2011.09.020

Aguilera, M., Cerdà-Cuéllar, M., Martínez, V., 2015. Antibiotic-induced dysbiosis alters host-bacterial interactions and leads to colonic sensory and motor changes in mice. Gut Microbes 6, 10-23. https://doi.org/10.4161/19490976.2014.990790

Assoni, L., Milani, B., Carvalho, M.R., Nepomuceno, L.N., Waz, N.T., Guerra, M.E.S., Converso, T.R., Darrieux, M., 2020. Resistance Mechanisms to Antimicrobial Peptides in Gram-Positive Bacteria. Front. Microbiol. 11. https://doi.org/10.3389/fmicb.2020.593215

Axelsson, L., Ahrné, S., 2000. Lactic Acid Bacteria, in: Priest, F.G., Goodfellow, M. (Eds.), Applied Microbial Systematics. Springer Netherlands, Dordrecht, pp. 367388. https://doi.org/10.1007/978-94-011-4020-1_13

Baindara, P., Singh, N., Ranjan, M., Nallabelli, N., Chaudhry, V., Pathania, G.L., Sharma, N., Kumar, A., Patil, P.B., Korpole, S., 2016. Laterosporulin10: a novel defensin like Class IId bacteriocin from Brevibacillus sp. strain SKDU10 with inhibitory activity against microbial pathogens. Microbiology (Reading) 162, 1286-1299. https://doi.org/10.1099/mic.0.000316

Becattini, S., Taur, Y., Pamer, E.G., 2016. Antibiotic-Induced Changes in the Intestinal Microbiota and Disease. Trends Mol Med 22, 458-478. https://doi.org/10.1016/j.molmed.2016.04.003

Bermúdez-Humarán, L.G., Langella, P., Cortes-Perez, N.G., Gruss, A., Tamez-Guerra, R.S., Oliveira, S.C., Saucedo-Cardenas, O., Montes de Oca-Luna, R., Le Loir, Y., 2003. Intranasal immunization with recombinant Lactococcus lactis secreting murine interleukin-12 enhances antigen-specific Th1 cytokine production. Infect Immun 71, 1887-1896. https://doi.org/10.1128/iai.71.4.1887-1896.2003

Bonning, B.C., Pal, N., Liu, S., Wang, Z., Sivakumar, S., Dixon, P.M., King, G.F., Miller, W.A., 2014. Toxin delivery by the coat protein of an aphid-vectored plant virus provides plant resistance to aphids. Nature Biotechnology 32, 102-105. https://doi.org/10.1038/nbt.2753

Boyanova, L., Hadzhiyski, P., Kandilarov, N., Markovska, R., Mitov, I., 2019. Multidrug resistance in Helicobacter pylori: current state and future directions. Expert Rev Clin Pharmacol 12, 909-915. https://doi.org/10.1080/17512433.2019.1654858

Braat, H., Rottiers, P., Hommes, D.W., Huyghebaert, N., Remaut, E., Remon, J.-P., van Deventer, S.J.H., Neirynck, S., Peppelenbosch, M.P., Steidler, L., 2006. A phase I 
trial with transgenic bacteria expressing interleukin-10 in Crohn's disease. Clin Gastroenterol Hepatol 4, 754-759. https://doi.org/10.1016/j.cgh.2006.03.028

Buchholz, C.J., Friedel, T., Büning, H., 2015. Surface-Engineered Viral Vectors for Selective and Cell Type-Specific Gene Delivery. Trends Biotechnol 33, 777-790. https://doi.org/10.1016/j.tibtech.2015.09.008

Cao, J., de la Fuente-Nunez, C., Ou, R.W., Torres, M.D.T., Pande, S.G., Sinskey, A.J., Lu, T.K., 2018. Yeast-Based Synthetic Biology Platform for Antimicrobial Peptide Production. ACS Synth Biol 7, 896-902. https://doi.org/10.1021/acssynbio.7b00396

Chen, Y., Zhu, X., Zhang, X., Liu, B., Huang, L., 2010. Nanoparticles modified with tumor-targeting scFv deliver siRNA and miRNA for cancer therapy. Mol Ther 18, 1650-1656. https://doi.org/10.1038/mt.2010.136

Choudhury, A., Islam, S.M.A., Ghidey, M.R., Kearney, C.M., 2020. Repurposing a drug targeting peptide for targeting antimicrobial peptides against Staphylococcus. Biotechnol Lett 42, 287-294. https://doi.org/10.1007/s10529-019-02779-y

Company, N., Nadal, A., La Paz, J.-L., Martínez, S., Rasche, S., Schillberg, S., Montesinos, E., Pla, M., 2014. The production of recombinant cationic $\alpha$-helical antimicrobial peptides in plant cells induces the formation of protein bodies derived from the endoplasmic reticulum. Plant Biotechnol J 12, 81-92. https://doi.org/10.1111/pbi.12119

Conlon, J.M., Ahmed, E., Pal, T., Sonnevend, A., 2010. Potent and rapid bactericidal action of alyteserin-1c and its $[\mathrm{E} 4 \mathrm{~K}]$ analog against multidrug-resistant strains of Acinetobacter baumannii. Peptides 31, 1806-1810. https://doi.org/10.1016/j.peptides.2010.06.032

Conlon, J.M., Demandt, A., Nielsen, P.F., Leprince, J., Vaudry, H., Woodhams, D.C., 2009. The alyteserins: two families of antimicrobial peptides from the skin secretions of the midwife toad Alytes obstetricans (Alytidae). Peptides 30, 10691073. https://doi.org/10.1016/j.peptides.2009.03.004

Correa, P., Piazuelo, M.B., 2011. Helicobacter pylori Infection and Gastric Adenocarcinoma. US Gastroenterol Hepatol Rev 7, 59-64.

Cover, T.L., Blaser, M.J., 1992. Purification and characterization of the vacuolating toxin from Helicobacter pylori. J Biol Chem 267, 10570-10575.

Cripe, T.P., Wang, P.-Y., Marcato, P., Mahller, Y.Y., Lee, P.W., 2009. Targeting Cancerinitiating Cells With Oncolytic Viruses. Mol Ther 17, 1677-1682. https://doi.org/10.1038/mt.2009.193 
de Vos, W.M., 1999. Gene expression systems for lactic acid bacteria. Curr Opin Microbiol 2, 289-295. https://doi.org/10.1016/S1369-5274(99)80050-2

Devocelle, M., 2012. Targeted Antimicrobial Peptides. Front. Immunol. 3. https://doi.org/10.3389/fimmu.2012.00309

Di, Y.P., Lin, Q., Chen, C., Montelaro, R.C., Doi, Y., Deslouches, B., 2020. Enhanced therapeutic index of an antimicrobial peptide in mice by increasing safety and activity against multidrug-resistant bacteria. Science Advances 6, eaay6817. https://doi.org/10.1126/sciadv.aay6817

Domańska, G., Motz, C., Meinecke, M., Harsman, A., Papatheodorou, P., Reljic, B., Dian-Lothrop, E.A., Galmiche, A., Kepp, O., Becker, L., Günnewig, K., Wagner, R., Rassow, J., 2010. Helicobacter pylori VacA toxin/subunit p34: targeting of an anion channel to the inner mitochondrial membrane. PLoS Pathog 6, e1000878. https://doi.org/10.1371/journal.ppat.1000878

Drouault, S., Corthier, G., Ehrlich, S.D., Renault, P., 1999. Survival, Physiology, and Lysis of Lactococcus lactis in the Digestive Tract. Appl Environ Microbiol 65, 4881-4886.

Eckert, R., He, J., Yarbrough, D.K., Qi, F., Anderson, M.H., Shi, W., 2006a. Targeted killing of Streptococcus mutans by a pheromone-guided "smart" antimicrobial peptide. Antimicrob. Agents Chemother. 50, 3651-3657. https://doi.org/10.1128/AAC.00622-06

Eckert, R., Qi, F., Yarbrough, D.K., He, J., Anderson, M.H., Shi, W., 2006b. Adding Selectivity to Antimicrobial Peptides: Rational Design of a Multidomain Peptide against Pseudomonas spp. Antimicrob Agents Chemother 50, 1480-1488. https://doi.org/10.1128/AAC.50.4.1480-1488.2006

Eckert, R., Sullivan, R., Shi, W., 2012. Targeted Antimicrobial Treatment to Re-establish a Healthy Microbial Flora for Long-term Protection. Adv Dent Res 24, 94-97. https://doi.org/10.1177/0022034512453725

El Shazely, B., Yu, G., Johnston, P.R., Rolff, J., 2020. Resistance Evolution Against Antimicrobial Peptides in Staphylococcus aureus Alters Pharmacodynamics Beyond the MIC. Front. Microbiol. 11. https://doi.org/10.3389/fmicb.2020.00103

Ferreyra, J.A., Ng, K.M., Sonnenburg, J.L., 2014. The Enteric Two-Step: nutritional strategies of bacterial pathogens within the gut. Cell Microbiol 16, 993-1003. https://doi.org/10.1111/cmi.12300

Fiocca, R., Necchi, V., Sommi, P., Ricci, V., Telford, J., Cover, T.L., Solcia, E., 1999. Release of Helicobacter pylori vacuolating cytotoxin by both a specific secretion pathway and budding of outer membrane vesicles. Uptake of released toxin and 
vesicles by gastric epithelium. J Pathol 188, 220-226. https://doi.org/10.1002/(SICI)1096-9896(199906)188:2<220::AIDPATH307>3.0.CO;2-C

Foegeding, N.J., Caston, R.R., McClain, M.S., Ohi, M.D., Cover, T.L., 2016. An Overview of Helicobacter pylori VacA Toxin Biology. Toxins (Basel) 8 . https://doi.org/10.3390/toxins8060173

Foligne, B., Dessein, R., Marceau, M., Poiret, S., Chamaillard, M., Pot, B., Simonet, M., Daniel, C., 2007. Prevention and treatment of colitis with Lactococcus lactis secreting the immunomodulatory Yersinia LcrV protein. Gastroenterology 133, 862-874. https://doi.org/10.1053/j.gastro.2007.06.018

Foo, J.H., Culvenor, J.G., Ferrero, R.L., Kwok, T., Lithgow, T., Gabriel, K., 2010. Both the p33 and p55 Subunits of the Helicobacter pylori VacA Toxin Are Targeted to Mammalian Mitochondria. Journal of Molecular Biology 401, 792-798. https://doi.org/10.1016/j.jmb.2010.06.065

Ganz, T., 2003. Defensins: antimicrobial peptides of innate immunity. Nature Reviews Immunology 3, 710-720. https://doi.org/10.1038/nri1180

Hancock, R.E., Diamond, G., 2000. The role of cationic antimicrobial peptides in innate host defences. Trends Microbiol 8, 402-410. https://doi.org/10.1016/s0966$842 \times(00) 01823-0$

Hancock, R.E.W., Sahl, H.-G., 2006. Antimicrobial and host-defense peptides as new anti-infective therapeutic strategies. Nature Biotechnology 24, 1551-1557. https://doi.org/10.1038/nbt1267

Hase, K., Murakami, M., Iimura, M., Cole, S.P., Horibe, Y., Ohtake, T., Obonyo, M., Gallo, R.L., Eckmann, L., Kagnoff, M.F., 2003. Expression of LL-37 by human gastric epithelial cells as a potential host defense mechanism against Helicobacter pylori. Gastroenterology 125, 1613-1625. https://doi.org/10.1053/j.gastro.2003.08.028

Holaskova, E., Galuszka, P., Frebort, I., Oz, M.T., 2015. Antimicrobial peptide production and plant-based expression systems for medical and agricultural biotechnology. Biotechnology Advances, BioTech 2014 and 6th Czech-Swiss Biotechnology Symposium 33, 1005-1023. https://doi.org/10.1016/j.biotechadv.2015.03.007

Ilver, D., Barone, S., Mercati, D., Lupetti, P., Telford, J.L., 2004. Helicobacter pylori toxin VacA is transferred to host cells via a novel contact-dependent mechanism. Cell Microbiol 6, 167-174. https://doi.org/10.1046/j.1462-5822.2003.00349.x 
Institute of Medicine (US) Forum on Microbial Threats, 2010. Antibiotic Resistance: Implications for Global Health and Novel Intervention Strategies: Workshop Summary, The National Academies Collection: Reports funded by National Institutes of Health. National Academies Press (US), Washington (DC).

Jeong, D.-W., Lee, J.-H., Kim, K.H., Lee, H.J., 2006. A food-grade expression/secretion vector for Lactococcus lactis that uses an alpha-galactosidase gene as a selection marker. Food Microbiol 23, 468-475. https://doi.org/10.1016/j.fm.2005.06.003

Kaplan, C.W., Sim, J.H., Shah, K.R., Kolesnikova-Kaplan, A., Shi, W., Eckert, R., 2011. Selective membrane disruption: mode of action of $\mathrm{C} 16 \mathrm{G} 2$, a specifically targeted antimicrobial peptide. Antimicrob Agents Chemother 55, 3446-3452. https://doi.org/10.1128/AAC.00342-11

Kau, A.L., Ahern, P.P., Griffin, N.W., Goodman, A.L., Gordon, J.I., 2011. Human nutrition, the gut microbiome and the immune system. Nature 474, 327-336. https://doi.org/10.1038/nature10213

Keenan, J., Day, T., Neal, S., Cook, B., Perez-Perez, G., Allardyce, R., Bagshaw, P., 2000. A role for the bacterial outer membrane in the pathogenesis of Helicobacter pylori infection. FEMS Microbiol Lett 182, 259-264. https://doi.org/10.1111/j.1574-6968.2000.tb08905.x

Kim, H., Jang, J.H., Kim, S.C., Cho, J.H., 2020. Development of a novel hybrid antimicrobial peptide for targeted killing of Pseudomonas aeruginosa. European Journal of Medicinal Chemistry 185, 111814. https://doi.org/10.1016/j.ejmech.2019.111814

Langdon, A., Crook, N., Dantas, G., 2016. The effects of antibiotics on the microbiome throughout development and alternative approaches for therapeutic modulation. Genome Med 8. https://doi.org/10.1186/s13073-016-0294-z

Lei, J., Sun, L., Huang, S., Zhu, C., Li, P., He, J., Mackey, V., Coy, D.H., He, Q., 2019. The antimicrobial peptides and their potential clinical applications. Am J Transl Res 11, 3919-3931.

Li, L., Guo, L., Lux, R., Eckert, R., Yarbrough, D., He, J., Anderson, M., Shi, W., 2010. Targeted Antimicrobial Therapy Against Streptococcus mutans Establishes Protective Non-cariogenic Oral Biofilms and Reduces Subsequent Infection. Int J Oral Sci 2, 66-73. https://doi.org/10.4248/IJOS10024

Li, R., Takala, T.M., Qiao, M., Xu, H., Saris, P.E.J., 2011. Nisin-selectable food-grade secretion vector for Lactococcus lactis. Biotechnol Lett 33, 797-803. https://doi.org/10.1007/s10529-010-0503-6 
Li, Y., 2011. Recombinant production of antimicrobial peptides in Escherichia coli: a review. Protein Expr Purif 80, 260-267. https://doi.org/10.1016/j.pep.2011.08.001

Madsen, S.M., Arnau, J., Vrang, A., Givskov, M., Israelsen, H., 1999. Molecular characterization of the $\mathrm{pH}$-inducible and growth phase-dependent promoter $\mathrm{P} 170$ of Lactococcus lactis. Mol Microbiol 32, 75-87. https://doi.org/10.1046/j.13652958.1999.01326.x

Madsen, S.M., Hindré, T., Le Pennec, J.-P., Israelsen, H., Dufour, A., 2005. Two acidinducible promoters from Lactococcus lactis require the cis-acting ACiD-box and the transcription regulator RcfB. Mol Microbiol 56, 735-746. https://doi.org/10.1111/j.1365-2958.2005.04572.x

Malanovic, N., Lohner, K., 2016. Antimicrobial Peptides Targeting Gram-Positive Bacteria. Pharmaceuticals (Basel) 9. https://doi.org/10.3390/ph9030059

Mannam, P., Jones, K.F., Geller, B.L., 2004. Mucosal vaccine made from live, recombinant Lactococcus lactis protects mice against pharyngeal infection with Streptococcus pyogenes. Infect Immun 72, 3444-3450. https://doi.org/10.1128/IAI.72.6.3444-3450.2004

Marty, C., Schwendener, R.A., 2005. Cytotoxic tumor targeting with scFv antibodymodified liposomes. Methods Mol Med 109, 389-402. https://doi.org/10.1385/159259-862-5:389

McClain, M.S., Cover, T.L., 2006. CHAPTER 24 - Helicobacter pylori vacuolating toxin, in: Alouf, J.E., Popoff, M.R. (Eds.), The Comprehensive Sourcebook of Bacterial Protein Toxins (Third Edition). Academic Press, London, pp. 468-490. https://doi.org/10.1016/B978-012088445-2/50029-9

Moncla, B.J., Pryke, K., Rohan, L.C., Graebing, P.W., 2011. Degradation of naturally occurring and engineered antimicrobial peptides by proteases. Adv Biosci Biotechnol 2, 404-408. https://doi.org/10.4236/abb.2011.26059

Morassutti, C., De Amicis, F., Skerlavaj, B., Zanetti, M., Marchetti, S., 2002. Production of a recombinant antimicrobial peptide in transgenic plants using a modified VMA intein expression system. FEBS Letters 519, 141-146. https://doi.org/10.1016/S0014-5793(02)02741-2

Mygind, P.H., Fischer, R.L., Schnorr, K.M., Hansen, M.T., Sönksen, C.P., Ludvigsen, S., Raventós, D., Buskov, S., Christensen, B., De Maria, L., Taboureau, O., Yaver, D., Elvig-Jørgensen, S.G., Sørensen, M.V., Christensen, B.E., Kjærulff, S., Frimodt-Moller, N., Lehrer, R.I., Zasloff, M., Kristensen, H.-H., 2005. Plectasin is a peptide antibiotic with therapeutic potential from a saprophytic fungus. Nature 437, 975-980. https://doi.org/10.1038/nature04051 
Neshani, A., Zare, H., Eidgahi, M.R.A., Chichaklu, A.H., Movaqar, A., Ghazvini, K., 2019. Review of antimicrobial peptides with anti-Helicobacter pylori activity. Helicobacter 24, e12555. https://doi.org/10.1111/hel.12555

Nicholson, J.K., Holmes, E., Kinross, J., Burcelin, R., Gibson, G., Jia, W., Pettersson, S., 2012. Host-gut microbiota metabolic interactions. Science 336, 1262-1267. https://doi.org/10.1126/science. 1223813

Norian, L.A., James, B.R., Griffith, T.S., 2011. Advances in Viral Vector-Based TRAIL Gene Therapy for Cancer. Cancers (Basel) 3, 603-620. https://doi.org/10.3390/cancers3010603

Nutrition, C. for F.S. and A., 2020. Microorganisms \& Microbial-Derived Ingredients Used in Food (Partial List) [WWW Document]. FDA. URL https://www.fda.gov/food/generally-recognized-safe-gras/microorganismsmicrobial-derived-ingredients-used-food-partial-list (accessed 5.25.21).

Oeemig, J.S., Lynggaard, C., Knudsen, D.H., Hansen, F.T., Nørgaard, K.D., Schneider, T., Vad, B.S., Sandvang, D.H., Nielsen, L.A., Neve, S., Kristensen, H.-H., Sahl, H.-G., Otzen, D.E., Wimmer, R., 2012. Eurocin, a new fungal defensin: structure, lipid binding, and its mode of action. J Biol Chem 287, 42361-42372. https://doi.org/10.1074/jbc.M112.382028

Palframan, S.L., Kwok, T., Gabriel, K., 2012. Vacuolating cytotoxin A (VacA), a key toxin for Helicobacter pylori pathogenesis. Front Cell Infect Microbiol 2. https://doi.org/10.3389/fcimb.2012.00092

Peschen, D., Li, H.-P., Fischer, R., Kreuzaler, F., Liao, Y.-C., 2004. Fusion proteins comprising a Fusarium -specific antibody linked to antifungal peptides protect plants against a fungal pathogen. Nature Biotechnology 22, 732-738. https://doi.org/10.1038/nbt970

Reinhardt, A., Neundorf, I., 2016. Design and Application of Antimicrobial Peptide Conjugates. Int J Mol Sci 17. https://doi.org/10.3390/ijms17050701

Robinson, K., Chamberlain, L.M., Schofield, K.M., Wells, J.M., Le Page, R.W., 1997. Oral vaccination of mice against tetanus with recombinant Lactococcus lactis. Nat Biotechnol 15, 653-657. https://doi.org/10.1038/nbt0797-653

Salih, B.A., 2009. Helicobacter pylori Infection in Developing Countries: The Burden for How Long? Saudi J Gastroenterol 15, 201-207. https://doi.org/10.4103/13193767.54743

Satoh, K., Hirayama, T., Takano, K., Suzuki-Inoue, K., Sato, T., Ohta, M., Nakagomi, J., Ozaki, Y., 2013. VacA, the vacuolating cytotoxin of Helicobacter pylori, binds to 
604

605

606

607

608

609

610

611

612

613

614

615

multimerin 1 on human platelets. Thromb J 11, 23. https://doi.org/10.1186/14779560-11-23

Singh, P.K., Solanki, V., Sharma, S., Thakur, K.G., Krishnan, B., Korpole, S., 2015. The intramolecular disulfide-stapled structure of laterosporulin, a class IId bacteriocin, conceals a human defensin-like structural module. FEBS J 282, 203-214. https://doi.org/10.1111/febs.13129

Snider, C.A., Voss, B.J., McDonald, W.H., Cover, T.L., 2016. Growth phase-dependent composition of the Helicobacter pylori exoproteome. J Proteomics 130, 94-107. https://doi.org/10.1016/j.jprot.2015.08.025

Steidler, L., Hans, W., Schotte, L., Neirynck, S., Obermeier, F., Falk, W., Fiers, W., Remaut, E., 2000. Treatment of murine colitis by Lactococcus lactis secreting interleukin-10. Science 289, 1352-1355. https://doi.org/10.1126/science.289.5483.1352

Steidler, L., Neirynck, S., Huyghebaert, N., Snoeck, V., Vermeire, A., Goddeeris, B., Cox, E., Remon, J.P., Remaut, E., 2003. Biological containment of genetically modified Lactococcus lactis for intestinal delivery of human interleukin 10. Nat Biotechnol 21, 785-789. https://doi.org/10.1038/nbt840

Steidler, L., REMAUT, R.E., Fiers, W., 2004. USE OF A CYTOKINE-PRODUCING LACTOCOCCUS TRIBE FOR TREATING COLUMN. DE69914932T2.

Steidler, L., Robinson, K., Chamberlain, L., Schofield, K.M., Remaut, E., Le Page, R.W., Wells, J.M., 1998a. Mucosal delivery of murine interleukin-2 (IL-2) and IL-6 by recombinant strains of Lactococcus lactis coexpressing antigen and cytokine. Infect Immun 66, 3183-3189. https://doi.org/10.1128/IAI.66.7.3183-3189.1998

Steidler, L., Viaene, J., Fiers, W., Remaut, E., 1998b. Functional display of a heterologous protein on the surface of Lactococcus lactis by means of the cell wall anchor of Staphylococcus aureus protein A. Appl Environ Microbiol 64, 342-345. https://doi.org/10.1128/AEM.64.1.342-345.1998

Strati, F., Pujolassos, M., Burrello, C., Giuffrè, M.R., Lattanzi, G., Caprioli, F., Troisi, J., Facciotti, F., 2021. Antibiotic-associated dysbiosis affects the ability of the gut microbiota to control intestinal inflammation upon fecal microbiota transplantation in experimental colitis models. Microbiome 9, 39. https://doi.org/10.1186/s40168-020-00991-x

Svenson, J., Stensen, W., Brandsdal, B.-O., Haug, B.E., Monrad, J., Svendsen, J.S., 2008a. Antimicrobial peptides with stability toward tryptic degradation. Biochemistry 47, 3777-3788. https://doi.org/10.1021/bi7019904 
Svenson, J., Stensen, W., Brandsdal, B.-O., Haug, B.E., Monrad, J., Svendsen, J.S., 2008b. Antimicrobial peptides with stability toward tryptic degradation. Biochemistry 47, 3777-3788. https://doi.org/10.1021/bi7019904

Telford, J.L., Ghiara, P., Dell'Orco, M., Comanducci, M., Burroni, D., Bugnoli, M., Tecce, M.F., Censini, S., Covacci, A., Xiang, Z., 1994. Gene structure of the Helicobacter pylori cytotoxin and evidence of its key role in gastric disease. J Exp Med 179, 1653-1658. https://doi.org/10.1084/jem.179.5.1653

van Asseldonk, M., Rutten, G., Oteman, M., Siezen, R.J., de Vos, W.M., Simons, G., 1990. Cloning of usp45, a gene encoding a secreted protein from Lactococcus lactis subsp. lactis MG1363. Gene 95, 155-160. https://doi.org/10.1016/03781119(90)90428-T

Vandenbroucke, K., de Haard, H., Beirnaert, E., Dreier, T., Lauwereys, M., Huyck, L., Van Huysse, J., Demetter, P., Steidler, L., Remaut, E., Cuvelier, C., Rottiers, P., 2010. Orally administered L. lactis secreting an anti-TNF Nanobody demonstrate efficacy in chronic colitis. Mucosal Immunology 3, 49-56. https://doi.org/10.1038/mi.2009.116

Vangay, P., Ward, T., Gerber, J.S., Knights, D., 2015. Antibiotics, Pediatric Dysbiosis, and Disease. Cell Host Microbe 17, 553-564. https://doi.org/10.1016/j.chom.2015.04.006

Vaucher, R. de A., Velho Gewehr, C. de C.V., Correa, A.P.F., Sant'Anna, V., Ferreira, J., Brandelli, A., 2011. Evaluation of the immunogenicity and in vivo toxicity of the antimicrobial peptide P34. Int J Pharm 421, 94-98. https://doi.org/10.1016/j.ijpharm.2011.09.020

Volzing, K., Borrero, J., Sadowsky, M.J., Kaznessis, Y.N., 2013. Antimicrobial Peptides Targeting Gram-negative Pathogens, Produced and Delivered by Lactic Acid Bacteria. ACS Synth. Biol. 2, 643-650. https://doi.org/10.1021/sb4000367

Voss, B.J., Gaddy, J.A., McDonald, W.H., Cover, T.L., 2014. Analysis of SurfaceExposed Outer Membrane Proteins in Helicobacter pylori. J Bacteriol 196, 2455 2471. https://doi.org/10.1128/JB.01768-14

Waterfield, N.R., Le Page, R.W., Wilson, P.W., Wells, J.M., 1995. The isolation of lactococcal promoters and their use in investigating bacterial luciferase synthesis in Lactococcus lactis. Gene 165, 9-15. https://doi.org/10.1016/03781119(95)00484-n

Wroblewski, L.E., Peek, R.M., Wilson, K.T., 2010. Helicobacter pylori and Gastric Cancer: Factors That Modulate Disease Risk. Clin Microbiol Rev 23, 713-739. https://doi.org/10.1128/CMR.00011-10 
Xiong, Y.Q., Hady, W.A., Deslandes, A., Rey, A., Fraisse, L., Kristensen, H.-H., Yeaman, M.R., Bayer, A.S., 2011. Efficacy of NZ2114, a Novel PlectasinDerived Cationic Antimicrobial Peptide Antibiotic, in Experimental Endocarditis Due to Methicillin-Resistant Staphylococcus aureus $\nabla$. Antimicrob Agents Chemother 55, 5325-5330. https://doi.org/10.1128/AAC.00453-11

Zarrinpar, A., Chaix, A., Xu, Z.Z., Chang, M.W., Marotz, C.A., Saghatelian, A., Knight, R., Panda, S., 2018. Antibiotic-induced microbiome depletion alters metabolic homeostasis by affecting gut signaling and colonic metabolism. Nature Communications 9, 2872. https://doi.org/10.1038/s41467-018-05336-9

Zha, J., Liu, X.-M., Zhu, J., Liu, S.-Y., Lu, S., Xu, P.-X., Yu, X.-L., Liu, R.-T., 2016. A $\mathrm{scFv}$ antibody targeting common oligomeric epitope has potential for treating several amyloidoses. Sci Rep 6, 36631. https://doi.org/10.1038/srep36631

Zhang, L., Wu, W.K.K., Gallo, R.L., Fang, E.F., Hu, W., Ling, T.K.W., Shen, J., Chan, R.L.Y., Lu, L., Luo, X.M., Li, M.X., Chan, K.M., Yu, J., Wong, V.W.S., Ng, S.C., Wong, S.H., Chan, F.K.L., Sung, J.J.Y., Chan, M.T.V., Cho, C.H., 2016. Critical Role of Antimicrobial Peptide Cathelicidin for Controlling Helicobacter pylori Survival and Infection. J Immunol 196, 1799-1809. https://doi.org/10.4049/jimmunol.1500021

Zhang, L., Yu, J., Wong, C.C.M., Ling, T.K.W., Li, Z.J., Chan, K.M., Ren, S.X., Shen, J., Chan, R.L.Y., Lee, C.C., Li, M.S.M., Cheng, A.S.L., To, K.F., Gallo, R.L., Sung, J.J.Y., Wu, W.K.K., Cho, C.H., 2013. Cathelicidin protects against Helicobacter pylori colonization and the associated gastritis in mice. Gene Therapy 20, 751760. https://doi.org/10.1038/gt.2012.92

Zorko, M., Jerala, R., 2010. Production of recombinant antimicrobial peptides in bacteria. Methods Mol Biol 618, 61-76. https://doi.org/10.1007/978-1-60761-594-1_5 